\title{
Cryptosporidiosis and Giardiasis in Buffaloes (Bubalus bubalis)
}

\author{
Monally Conceição Costa de Aquino ${ }^{1}$, Sandra Valéria Inácio ${ }^{2}$, \\ Fernando de Souza Rodrigues ${ }^{3}$, Luiz Daniel de Barros ${ }^{3}$, João Luis Garcia ${ }^{3}$, \\ Selwyn Arlington Headley ${ }^{4,5}$, Jancarlo Ferreira Gomes ${ }^{6,7}$ and \\ Katia Denise Saraiva Bresciani ${ }^{2 *}$
}

${ }^{1}$ Estácio de Sá University, Rio de Janeiro, Brazil, ${ }^{2}$ School of Veterinary Medicine Araçatuba, São Paulo State University (UNESP), Araçatuba, Brazil, ${ }^{3}$ Laboratory of Animal Protozoology, Department of Preventive Veterinary Medicine, State University of Londrina, Londrina, Brazil, ${ }^{4}$ Comparative Pathology Shared Resources Laboratory, Masonic Cancer Center, University of Minnesota, Saint Paul, MN, United States, ${ }^{5}$ Laboratory of Animal Pathology, Department of Preventive Veterinary Medicine, State University of Londrina, Londrina, Brazil, ${ }^{6}$ School of Medical Sciences, University of Campinas, São Paulo, Brazil, ' Laboratory of Image Data Science, Institute of Computing, University of Campinas, São Paulo, Brazil

\section{OPEN ACCESS}

Edited by:

Ferran Jori,

UMR ASTRE-CIRAD, France

Reviewed by:

David Carmena,

Carlos III Health Institute (ISCIII), Spain Hans-Peter Fuehrer, University of Veterinary Medicine,

Vienna, Austria

*Correspondence:

Katia Denise Saraiva Bresciani katia.bresciani@unesp.br

Specialty section: This article was submitted to Veterinary Epidemiology and Economics,

a section of the journal Frontiers in Veterinary Science

Received: 01 May 2020 Accepted: 16 September 2020 Published: 28 October 2020

Citation: de Aquino MCC, Inácio SV, Rodrigues FdS, de Barros $L D$, Garcia JL, Headley SA, Gomes JF and Bresciani KDS (2020) Cryptosporidiosis and Giardiasis in

Buffaloes (Bubalus bubalis).

Front. Vet. Sci. 7:557967. doi: 10.3389/fvets.2020.557967
Cryptosporidium spp. and Giardia duodenalis infect the gastrointestinal tracts of animals and humans. Both parasite groups are distributed worldwide and cause significant economic losses in animal productivity. Infected hosts presenting with and without clinical manifestations can eliminate infective forms of these protozoa, which are particularly important to One Health. Compared to the published research on cattle, relatively few studies have examined the epidemiology of cryptosporidiosis and giardiasis in buffaloes. This short review describes the global occurrence of Cryptosporidium spp. and G. duodenalis in buffaloes, including the molecular techniques employed for the identification of species/assemblages and genotypes of these protozoa. Genetic analyses of isolates of $G$. duodenalis and Cryptosporidium spp. from various sources (environmental, animal, and human) have been performed to investigate their epidemiology. In buffaloes, the species Cryptosporidium parvum, Cryptosporidium ryanae, Cryptosporidium bovis, and Cryptosporidium suis-like have been characterized, as well as assemblages $A$ and $E$ of $G$. duodenalis. We demonstrate that buffaloes can be infected by species of Cryptosporidium spp. and $G$. duodenalis assemblages with zoonotic potential. Epidemiological studies that utilize molecular biology techniques represent an important resource for efforts to control and prevent the spread of these protozoans.

Keywords: Cryptosporidium, Giardia, water buffalo, zoonosis, genotypes, assemblages

\section{INTRODUCTION}

Cryptosporidium spp. and Giardia duodenalis (synonym: Giardia lamblia, Giardia intestinalis) are unicellular protozoan parasites that infect the intestinal tracts of humans and animals (1-3). Although these parasites possess biological differences, they are frequently discussed together because they share transmission pathways and cause diseases in the gastrointestinal tract (4).

Oocysts and cysts are transmitted via the fecal-oral route following direct or indirect contact with the transmissible stages. Possible propagation mechanisms of Cryptosporidium spp. and G. duodenalis include from animal to animal, from person to person, through zoonotic transmission, via contaminated food (5), by water delivery through drinking water, and in the course of 
recreational activities (6). Insects can also act as mechanical carriers of these protozoa (7). These parasitic forms of $G$. duodenalis and Cryptosporidium spp. remain infectious for months in environments with favorable temperature and humidity conditions, which enables the perpetuation of the biological cycle and parasitic spread (4).

Ruminants are frequently considered a major source of excretion of Cryptosporidium spp. and G. duodenalis for humans $(8,9)$. Although most studies on this topic have investigated cattle, water buffaloes can also become infected and excrete Cryptosporidium spp. oocysts (Table 1) and G. duodenalis cysts (Table 2). In general, young buffaloes are more affected by these agents than are older animals $(11,16,18,25,27,34)$.

Cryptosporidium spp. and G. duodenalis cause mild and/or moderate disease, with diarrhea being the main clinical sign. There are few reports describing the economic burden of Cryptosporidium spp. and G. duodenalis infection in ruminants. The costs of treatment, reduced feed conversion, production inefficiency, and the involvement of many animals in the herd cause considerable economic losses on farms worldwide $(25,35)$. Dairy calves determined to be negative for Cryptosporidium or G. duodenalis by immunofluorescence microscopy showed higher average daily gain than did calves that were positive for these parasites (36).

The application of molecular approaches for the identification of these two parasites has led to significant advances in knowledge regarding the epidemiology of these protozoans, with different species being characterized (37).

Molecular analysis of human and animal isolates has demonstrated that $G$. duodenalis is a complex species, with eight assemblages being recognized. Assemblages $\mathrm{A}$ and $\mathrm{B}$ are observed in humans and other mammals, assemblages $C$ and $D$ are specific to dogs and other canids, assemblage $\mathrm{E}$ is found in hoofed animals, including livestock, assemblage $\mathrm{F}$ is detected in cats, assemblage $\mathrm{G}$ is found in rodents, and assemblage $\mathrm{H}$ is observed in pinnipeds (38).

To date, at least 38 species of Cryptosporidium spp. have been recognized by molecular characterization (39-41), with 73 genotypes (42-44) and 17 species having been identified in humans (45).

Cryptosporidium spp. and G. duodenalis may represent a problem to the buffalo industry due to their economic cost and the risk of human exposure associated with oocysts and cysts eliminated in the environment by infected hosts. Thus, in this

TABLE 1 | Occurrence of Cryptosporidium spp. in buffaloes worldwide using different diagnostic techniques.

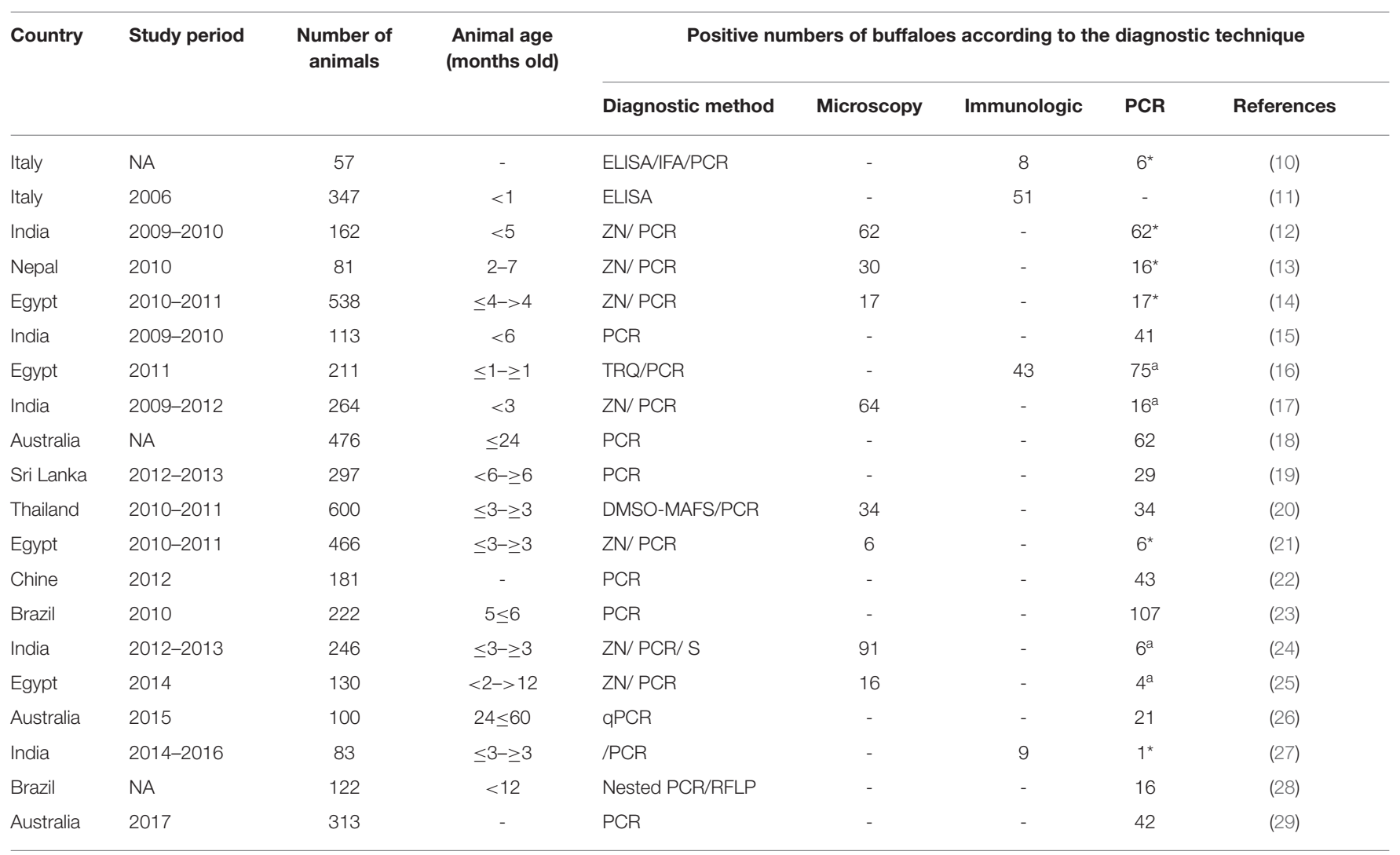

${ }^{*} P C R$ was performed only on positive samples by a previous screening method.

a PCR was performed on only some of the positive samples by the screening method.

PCR, Polimerase Chain Reaction; ZN, Ziehl-Neelsen; ELISA, Enzyme-Linked Immunosorbent Assay; IFA, Immunofluorescence Assays; TRQ, Test RIDA ${ }^{\circledR} Q U I C K ;$ DMSO- MAFS, DMSODMSO- modified acid-fast stain; IM, Imunofluorescent Microscopy; S, Sheather.

NA, not available. 
TABLE 2 | Occurrence of G. duodenalis in buffaloes worldwide using different diagnostic techniques.

\begin{tabular}{|c|c|c|c|c|c|c|c|c|}
\hline \multirow[t]{2}{*}{ Country } & \multirow[t]{2}{*}{ Study period } & \multirow{2}{*}{$\begin{array}{l}\text { No of. } \\
\text { animals }\end{array}$} & \multirow{2}{*}{$\begin{array}{c}\text { Animal age } \\
\text { (months) }\end{array}$} & \multicolumn{5}{|c|}{ Positive numbers of buffaloes according to the diagnostic technique } \\
\hline & & & & $\begin{array}{l}\text { Diagnostic } \\
\text { method }\end{array}$ & Microscopy & Immunologic & PCR & References \\
\hline Italy & NA & 57 & - & ELISA/IFA/PCR & - & 15 & $8^{*}$ & $(10)$ \\
\hline Italy & 2006 & 347 & $<1$ & ELISA & - & 63 & - & $(11)$ \\
\hline Australia & NA & 476 & $\leq 24$ & PCR & - & - & 62 & (18) \\
\hline Sri Lanka & 2012-2013 & 297 & $<6-\geq 6$ & PCR & - & - & 2 & (19) \\
\hline Egypt & 2011 & 211 & $\leq 1-\geq 1$ & $\begin{array}{l}\text { Test } \\
\text { RIDA }{ }^{\circledR} \text { QUICK/PCR }\end{array}$ & 10 & - & 10 & (30) \\
\hline India & 2012 & 22 & - & IMS/DFA & - & 9 & - & (31) \\
\hline Egypy & 2013-2014 & 100 & $1<4$ & $\begin{array}{l}\text { DSM/ FEST / } \\
\text { S/PCR }\end{array}$ & 25 & - & 25 & (32) \\
\hline India & 2014-2016 & 83 & $\leq 3-\geq 3$ & IM/PCR & - & 9 & 1 & (27) \\
\hline Brazil & 2016 & 183 & $\leq 6$ & PCR & - & - & 12 & (33) \\
\hline Australia & 2017 & 313 & - & PCR & - & - & 14 & (29) \\
\hline
\end{tabular}

${ }^{*} P C R$ was performed only on positive samples by a previous screening method.

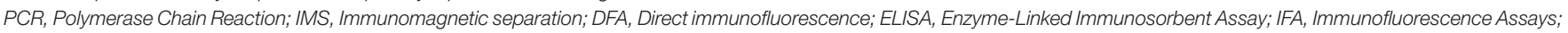
Direct smear method; Formalin-ether sedimentation technique; IM, Immunofluorescent microscopy; S, Sheather; RIDA ${ }^{\circledR} Q U I C K . ~ N A$, not available.

review, we demonstrate the global occurrence of these protozoa, emphasizing the importance of the molecular characterization of their species/assemblages and genotypes reported in buffaloes.

\section{DIAGNOSTIC METHODS}

Cryptosporidiosis and giardiasis can be diagnosed by a wide variety of parasitological, serological, and molecular techniques (4, 46-48).

Regarding the parasitological diagnosis technique, the identification of the morphological structures of the Cryptosporidium spp. oocysts and G. duodenalis trophozoites or cysts is important, with $G$. duodenalis being diagnosed by direct microscopic observation of the trophozoites or cysts in feces. Trophozoites can be observed by direct microscopic examination of freshly collected samples, which are immediately prepared with saline solution at $37^{\circ} \mathrm{C}(49)$. Concentration techniques, such as zinc sulfate (50), sucrose (51), formalin (52), and the "three fecal test" (TF test) (53), are recommended before the observation of cysts since these methods promote an increase in diagnostic sensitivity. Centrifugal flotation with zinc sulfate is one of the most commonly employed methods for the detection of $G$. duodenalis from fecal samples; however, sucrose flotation works adequately well, and it is generally employed in ruminant samples since oocysts of Eimeria spp. and Cryptosporidium spp. may also be encountered (4).

Various staining procedures can be used to differentiate between Cryptosporidium spp. oocysts and G. duodenalis cysts from coexisting protists and for excluding similarities from environmental or fecal debris. Smear preparations stained by the trichome and iodine or iron hematoxylin methods can be utilized to assist in the detection of various stages of $G$. duodenalis (49). The most frequently used routine techniques for examining stained slides to identify Cryptosporidium spp. are the modified Ziehl-Neelsen $(54,55)$, modified Kinyoun $(56,57)$, and methylene blue safranin $(58,59)$ stains. Additionally, the negative coloring observed with the malachite green technique $(53,60)$ can be used. The centrifugal flotation technique with Sheather's solution (61), which uses brightfield or phase contrast optical microscopy, can be employed to visualize oocysts (8). However, differentiating between Cryptosporidium species/genotypes using microscopy is not possible because oocysts are similar in shape and overlap in size (37).

Immunological methods have higher sensitivity and specificity than light microscopy in characterizing diverse types of samples $(49,62,63)$. Monoclonal antibodies targeting antigens in fecal samples are sensitive diagnostic methods $(64,65)$. Antigens of Cryptosporidium spp. and G. duodenalis in fecal contents can be detected by direct immunofluorescence assay $(63,66)$, ELISA (67-69), and rapid solid-phase qualitative immunochromatography assays (67). Some immunoenzymatic tests can be employed to detect infection in animals that are not eliminating cysts in the feces (70), which means that these tests can be utilized to screen large numbers of animals rapidly (67). However, these methods have the disadvantage of not being able to identify species or genotypes (45).

The application of molecular techniques has resulted in expanded knowledge regarding the taxonomy and epidemiology of Cryptosporidium spp. and $G$. duodenalis. Molecular diagnostics are widely used to differentiate Cryptosporidium spp. and G. duodenalis species or genotypes (35). Therefore, such methods as polymerase chain reaction (PCR), real-time PCR, or multiplex PCR together with DNA sequencing can identify species/assemblages with high sensitivity and specificity, and these techniques can be employed to identify sources of transmission as well as the zoonotic potential of these two parasites (71-73).

Genotyping targeting the small subunit of the ribosomal RNA gene (ssu rRNA) aligned with PCR and sequencing 
the restriction fragment polymorphism (RFLP) are sensitive molecular tools used in the detection of Cryptosporidium spp. DNA in fecal and environmental samples $(74,75)$. Other genetic regions have also been studied, such as the $70-\mathrm{kDa}$ heat shock protein ( $h s p 70)$, thrombospondin-related adhesive proteins, Cryptosporidium spp. oocyst wall protein (cowp), and actin genes (76).

The $60-\mathrm{kDa}$ glycoprotein $(g p 60)$ is located on the surface of the apical region of invasive stages of the parasite. This gene is a highly polymorphic marker that is widely used in Cryptosporidium spp. subtyping because of its high polymorphism and relevance to parasite biology, and the use of gp60 subtyping has identified human-specific, animal-specific, and zoonotic subtypes for Cryptosporidium parvum speciesspecific subtypes (37). More than 20 gp60 genotype families of $C$. parvum have been described, including several subtypes within each family, with families IIa and IId being identified from ruminants and humans and recognized as zoonotic. The IIa family and subtype IIaA15G2R1 are frequently identified in calves $(3,77)$.

Many genetic markers have been employed for the molecular characterization of $G$. duodenalis using degenerated primers, such as the ssu rRNA, glutamate dehydrogenase ( $g d h)$, elongation factor 1-alfa $(e l 1-\alpha)$, triose-phosphate isomerase (tpi), or genes uniquely associated with the parasite, such as beta-giardin $(b g)$ (78). The ssu rRNA gene is strongly conserved and can be utilized to identify $G$. duodenalis assemblages, but it is of little use for studies where genetic variation within assemblages needs to be determined (78). Consequently, the tpi, $b g$, and $g d h$ sequences are employed because polymorphism enables the characterization of the genetic heterogeneity of this parasite (79) as well as its zoonotic potential $(78,80)$. However, molecular methods are mostly restricted to research and specialized laboratories (37).

\section{EPIDEMIOLOGY}

Infections by Cryptosporidium spp. and G. duodenalis in water buffalo (Bubalus bubalis) have been less thoroughly well-investigated compared with other bovid species. Tables 1, 2 summarize the occurrence of these protozoa in different buffalo populations.

According to the findings described in Table 1, the infection rates of cryptosporidiosis reported in buffaloes ranged from $1.3 \%$ (Egypt) to $48.2 \%$ (Brazil). However, the epidemiology of giardiasis has been more heavily studied in cattle, with few reports describing G. duodenalis infections in buffaloes (Table 2), and a prevalence ranging from $1.3 \%$ (Sri Lanka) to $10.5 \%$ (India) was reported.

Differences in the prevalence of infection for Cryptosporidium spp. and G. duodenalis in buffaloes are common among epidemiological studies. The discrepancies in the reported infection rates may be attributed to the differences in environmental conditions, management practices, time between collection and processing of fecal samples, the diagnostic techniques used, age, and the number of animals analyzed in each study.
High population density, with more than 100 buffaloes being raised on a farm, intensive management systems where buffalo calves are reared at high density (11), poor or inadequate hygiene, concrete floor (81), canalized or underground water sources $(16,81)$, and the winter period $(24,81)$, as well as rainy periods (17), were relevant risk factors associated with the occurrence of infection by Cryptosporidium spp.

In preweaned calves, C. parvum causes high morbidity associated with profuse diarrhea, lethargy, anorexia, and dehydration (82). The clinical signs are evident 3-5 days after infection, and the duration of the clinical signs can vary between 4 and 18 days (83). Diarrhea is accompanied by the excretion of large amounts of oocysts, which can be subsequently dispersed within the environment (82).

Some studies have observed an association between infection by Cryptosporidium spp. and diarrhea in buffalo calves $(17,24$, $34,81)$, with a higher occurrence of infection being observed in the 1st months of age $(24,25,34)$.

In calves of cattle and buffaloes from the Mumbai region of India, diarrheic feces showed a higher prevalence of Cryptosporidium spp. than did apparently normal feces. The highest prevalence was observed in the youngest group, declining gradually with advancing age, with the lowest prevalence being observed in adults, indicating an inverse correlation between the prevalence rate and age of the host (24). The presence of Cryptosporidium spp. oocysts in the feces of water buffaloes without clinical signs was verified at 6 weeks of age, which suggests that asymptomatic individuals are potential sources of infection (84).

Mixed infections by Cryptosporidium spp. and G. duodenalis in buffalo were detected by real-time PCR in 36\% of animals (cattle and buffaloes) from Egypt (30). These parasites may be detected together in calves with diarrhea, and coinfection with other pathogens has also been reported (84).

In Egypt, the occurrence of Cryptosporidium spp. was 9.5\% $(17 / 179)$ in calves of buffaloes and absent in 359 adult water buffaloes (14). In some studies, C. parvum was identified only in buffaloes $<6$ months of age $(18,34)$. However, in Northeast Australia, all samples positive for $C$. parvum were isolated from adult buffaloes ( $2-5$ years), indicating that this species can also commonly infect adult buffaloes (26). In Thailand, C. parvum infection was identified in all age groups, with no significant difference in the infection rates being observed among the age groups assessed (20).

The epidemiology of giardiasis has been more studied in cattle, and there are few reports of $G$. duodenalis infections in buffaloes (Table 2). In Pakistan, $2.7 \times 10^{2}$ cysts per gram of feces of $G$. duodenalis were excreted in fecal samples with normal consistency. Additionally, in cases of diarrhea, the intensity of elimination was higher $\left(4.3 \times 10^{3}\right.$ cysts per gram of feces). In that same study, buffalo calves ( $\leq 1$ year) had significantly higher cyst prevalence (85).

The prevalence of G. duodenalis in Australia was 13\% $(62 / 476)$ with the identification of assemblages A (11.8\%) and E (1.2\%), respectively.

In an overpopulated province of Egypt, G. duodenalis cyst/trophozoites were observed in $20 \%$ of fecal samples from 
people and in $25 \%$ of buffalo calves by nested PCR. Contact with calf manure and inappropriate personal hygiene practices, such as hand washing and changing shoes after handling the animals, were considered to be risk factors significantly associated with giardiasis (32).

\section{MOLECULAR ASPECTS}

Molecular diagnostic tools play an important role in understanding the transmission of Cryptosporidium spp. and $G$. duodenalis, mainly due to the existence of many morphologically identical species and genotypes within both groups of protozoa. Thus, these tools are required for the differentiation of these species and genotypes (86).

Although the molecular epidemiology of Cryptosporidium spp. and $G$. duodenalis is well-studied in cattle, studies are scarce in buffaloes. Cattle are commonly infected by four species of Cryptosporidium, with C. parvum being predominant in preweaned calves, Cryptosporidium bovis and Cryptosporidium ryanae predominant in the postweaning phase, and Cryptosporidium andersoni predominant in adults $(45,75$, 87). However, differences in the occurrence of different species according to age groups in buffaloes were not observed.

Previous studies have determined the species of Cryptosporidium infecting buffaloes in different countries; C. parvum, C. ryanae, C. bovis, and a genotype similar to that of Cryptosporidium suis were identified (Table 3). Phylogenetic analysis using a range of sequences of the ssu rRNA gene of Cryptosporidium spp. retrieved from the GenBank database from various geographical regions supports the classification of the species and genotypes of Cryptosporidium spp. in buffaloes (Figure 1).

Cryptosporidium parvum is the most frequently reported zoonotic species that infects humans and ruminants worldwide (8). Numerous studies have been conducted to subtype C. parvum in farm animals, especially calves, to characterize the transmission dynamics and zoonotic potential of C. parvum. Table 3 shows that most of the studies using $g p 60$ and sequencing analysis have observed that buffaloes are commonly infected with the IIa family. Additionally, family IId has been found in buffaloes in Egypt (14, 21, 25, 30) and India (27).

Cryptosporidium ryanae infects ruminants and has been widely reported in calves from different age groups worldwide $(13,14,18,19,22-24,28,29)$. Data from recent studies suggest that there is a host-adapted C. ryanae in water buffaloes, as reflected by the high occurrence of this species in these animals $(13,23,28)$. Some findings show that the genotypes of C. ryanae found in water buffaloes are different from those identified in cattle $(13,18,22,23)$. Therefore, further research is warranted to determine the taxonomic status and host specificity of these genotypes found in water buffaloes (19).

Cryptosporidium bovis is predominantly a parasite of livestock and has been reported in buffaloes on several occasions $(16,18$, $22,26,27)$. Due to the lower occurrence of this species compared

\begin{tabular}{|c|c|c|c|c|c|}
\hline Country & $\begin{array}{c}\text { Number of } \\
\text { animals }\end{array}$ & Genes & Species of Cryptosporidium & gp60 genotype & References \\
\hline Italy & 57 & ssu rRNA & C. parvum & - & $(10)$ \\
\hline India & 162 & ssu rRNA & Cyptosporidium spp. & - & $(12)$ \\
\hline Nepal & 81 & ssu rRNA & C. ryanae & - & (13) \\
\hline India & 113 & ssu rRNA & Cyptosporidium spp. & - & $(15)$ \\
\hline India & 264 & ssu rRNA & C. parvum & - & $(17)$ \\
\hline Australia & 476 & ssu rRNA & C. bovis. C. parvum. C. suis like. C. ryanae & - & $(18)$ \\
\hline Egypt & 211 & ssu rRNA, gp60 & C. bovis. C. parvum. C. ryanae & IlaA15G1R1(1). IdA20G1 (1) & $(16)$ \\
\hline Egypt & 538 & ssu rRNA, gp60 & C. parvum. C. ryanae (10) & IlaA15G1R1 (5). IIdA20G1 (2) & $(14)$ \\
\hline Egypt & 466 & ssu rRNA, gp60 & C. parvum. C. ryanae & & $(21)$ \\
\hline Sri Lanka & 297 & ssu rRNA, gp60 & C. ryanae. C. suis like & - & (19) \\
\hline Thailand & 600 & ssu rRNA & C. parvum.C. ryanae & - & (20) \\
\hline Chine & 181 & ssu rRNA & C. bovis. C. ryanae & - & $(22)$ \\
\hline Brazil & 222 & ssu rRNA, gp60, cowp & C. parvum. C. ryanae. C. suis like & IlaA15G2R1(2) & (23) \\
\hline Egypt & 130 & ssu rRNA, gp60, cowp & C. parvum & IIdA20G1 (4) & $(25)$ \\
\hline India & 246 & ssu rRNA & C. parvum. C. ryanae & - & $(24)$ \\
\hline Australia & 100 & ssu rRNA, gp60 & C. bovis. C. parvum & IlaA18G3R1(5) IIdA19G1 (4). IdA15G1 (1) & $(26)$ \\
\hline India & 83 & ssu rRNA, gp60 & C. bovis. C. parvum & IIA15GR1 (1) & $(27)$ \\
\hline Brazil & 122 & ssu rRNA, gp60 & C. parvum. C. ryanae & IIA20G1R1 (4) & $(28)$ \\
\hline Australia & 313 & ssu rRNA & C. ryanae & - & (29) \\
\hline
\end{tabular}

ssu rRNA, Small Subunit of the ribosomal RNA gene; gp60, 60 kDa glycoprotein gene; cowp, Cryptosporidium spp. oocyst wall protein. 


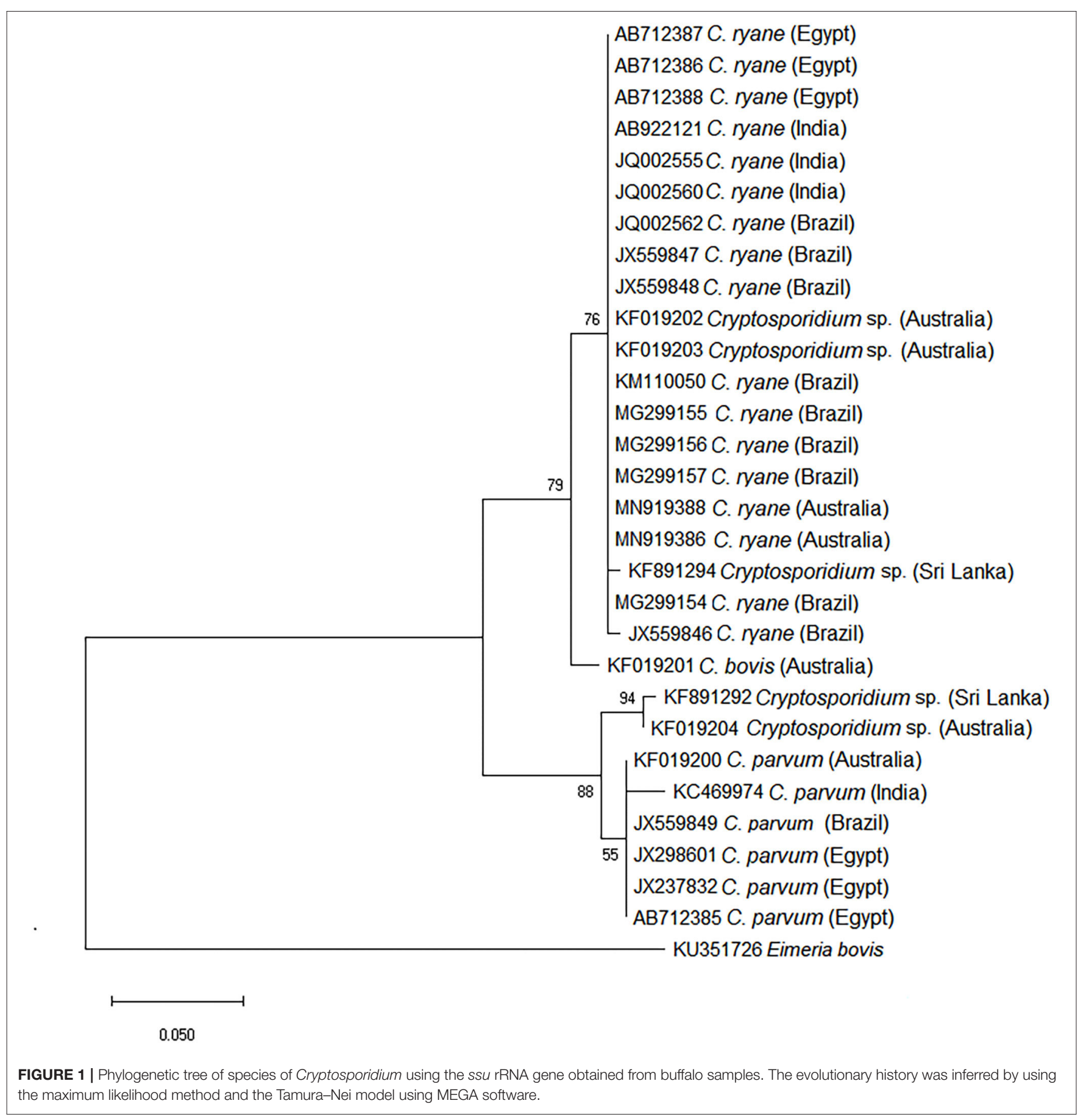

to other species of Cryptosporidium spp. reported in buffaloes, the possibility of a higher affinity of C. bovis for Bos taurus or Bos indicus was considered than for B. bubalis (18).

The ssu rRNA sequences of $C$. suis-like obtained from buffaloes in Brazil (23), Australia (18), and Sri Lanka (19) were similar to those previously identified in cattle (88-90). Based on the analysis of other genetic markers, such as $h s p 70$ and actin, it was observed that the sequences generated were clearly different from those of C. suis (23).
Regarding G. duodenalis infection in buffaloes, the first molecular characterization of $G$. duodenalis was performed in Italy with the detection of assemblage $\mathrm{E}$ and assemblage A, subassemblage AI. Based on this finding, buffaloes were suggested to contribute to environmental contamination due to the elimination of potentially infectious parasitic cysts in humans (10).

There are a limited number of studies on giardiasis in buffaloes, and in most of these, the dominant assemblage 
identified was assemblage E (Table 4); however, zoonotic assemblage A was reported to be predominant in buffaloes from Australia (18). The predominance of this assemblage was unexpected (18).

Few studies have typed assemblage A isolates in buffaloes, but subassemblage AI was the most common (10). Studies on the prevalence of $G$. duodenalis in cattle observed the existence of different subtypes of assemblage $\mathrm{E}$ identified by the multilocus genotyping scheme (MLG) based on the $b g, g d h$, and tpi genes $(91,92)$. The differences in the distribution of $G$. duodenalis assemblage E MLGs from cattle likely indicate geographical segregation (91).

\section{PUBLIC HEALTH IMPACT}

Due to the close relationship of these protozoans with poor basic sanitation and low population purchasing power, Cryptosporidium spp. and G. duodenalis were included in the World Health Organization's Neglected Diseases Initiative (93).

Water transmission of Cryptosporidium spp. and $G$. duodenalis is particularly important (94), with outbreaks being reported in several countries $(95,96)$. Most people in undeveloped countries do not have access to good quality water. Consequently, the contamination of drinking and bathing water with these two pathogens and the use of sewage for agricultural purposes pose a serious threat to millions of individuals worldwide (97).

The transmission of Cryptosporidium spp. and G. duodenalis has also been associated with the consumption of contaminated food due to the use of fertilizers based on animal feces (manure), the use of untreated water for the irrigation of farmland, and runoff from feedlots. In addition, food can be contaminated during harvesting, packaging, transportation, and preparation under unhygienic conditions (98).

Human infections by Cryptosporidium spp. are commonly caused by Cryptosporidum hominis and C. parvum $(1,99)$, although other species have previously demonstrated zoonotic potential, such as Cryptosporidum ubiquitum (100),
Ctenocephalides canis and Ctenocephalides felis (101-103), Crytosporidium muris (104, 105), C. suis (106), Crytosporidium cuniculus (107, 108), and Crytosporidium meleagridis (109-111).

Assemblages A and B of $G$. duodenalis can be observed in both humans and animals. Less frequently, other G. duodenalis genotypes have been only occasionally detected in humans $(112,113)$, with the possible exception of assemblage E, which has recently been detected in substantial numbers of human cases in rural areas of Egypt $(25,30,114)$, Brazil (115), and Australia (116).

Cattle are recognized as a major contributor to zoonotic sources because the species and genotypes of Cryptosporidium spp. and G. duodenalis that infect humans have also been isolated from cattle (35).

Especially in developing countries, these parasites cause diarrhea in malnourished children under 5 years of age (117). Cryptosporidiosis in immunocompetent individuals is considered self-limiting, but with the appearance of the acquired immunodeficiency syndrome (HIV), opportunistic infections have been associated with more serious and even fatal clinical manifestations in immunosuppressed individuals $(35,118,119)$.

The common occurrence of C. parvum subtypes IIaA15G1R1 and IIdA20G1 in buffaloes and humans in Egypt, respectively $(16,25)$, highlights the importance of zoonotic transmission with a special emphasis to the potential role of these animals as significant reservoirs of infection to humans.

In humans, most of the infections related to G. duodenalis are asymptomatic; however, acute or chronic diarrhea, dehydration, abdominal pain, nausea, vomiting, and weight loss can occur $(120,121)$. Most cases occur in individuals who are under 5 years of age, malnourished, and immunocompromised (80). Functional intestinal disorders, such as irritable bowel syndrome, can be associated with a previous infection (122). Infected children may show developmental delays, decreased cognitive function and nutritional status (123).

Among the assemblages of $G$. duodenalis, assemblages $\mathrm{A}$ and $B$ have the broadest host specificity, having been known to infect humans and various other mammals (124). Both assemblages can

TABLE 4 | Assemblages and sub-assemblages of $G$. duodenalis in buffaloes worldwide.

\begin{tabular}{|c|c|c|c|c|c|c|c|}
\hline Country & Study period & $\begin{array}{l}\text { Number of } \\
\text { animals }\end{array}$ & $\begin{array}{c}\text { Animal age } \\
\text { (months) }\end{array}$ & Genes & Assemblages & $\begin{array}{c}\text { Sub- } \\
\text { assemblages }\end{array}$ & References \\
\hline Italy & NA & 57 & - & $b g$ & A. E & $\mathrm{A} 1$ & (10) \\
\hline Sri Lanka & 2012-2013 & 297 & $<6-\geq 6$ & tpi & $\mathrm{E}$ & - & (19) \\
\hline Egypt & 2011 & 211 & $\mathrm{~A} / \mathrm{C}$ & bg. gdh. tpi & $E$ & - & (30) \\
\hline India & 2014-2016 & 83 & $\mathrm{~A} / \mathrm{C}$ & ssu rRNA. tpi & A & - & (27) \\
\hline Brazil & 2016 & 183 & $\geq 6$ & ssu rRNA. bg. gdh. tpi & $E$ & - & (33) \\
\hline Australia & 2017 & 313 & - & bg. gdh & $\mathrm{E}$ & - & (29) \\
\hline
\end{tabular}

ssurRNA, Small Subunit of the ribosomal RNA gene; bg, $\beta$-giardin gene; gdh, Glutamate dehydrogenase gene; tpi, triosephosphate isomerase gene; A/c, Adults/calves; NA, not available. 
be transmitted zoonotically, indicating a significant public health impact, and there are reports of farmers being infected with these assemblages (37). However, assemblage B has not been reported in buffaloes (124).

Assemblage $\mathrm{E}$ is considered species-specific; however, there are reports of humans being infected with this assemblage, and it was suggested that this assemblage might present an emerging anthropozoonotic cycle $(30,114-116,125)$.

In Ismailia, one of the most densely populated provinces of Egypt (regarding livestock and people), fecal samples from children, cattle, and buffaloes were examined for the detection of $G$. duodenalis coproantigens and analyzed by MLG ( $b g$, $g d h$, and tpi). Assemblage B was dominant in humans, while assemblage $\mathrm{E}$ was more frequent in ruminants and was detected in two children, indicating a potential route for anthropogenic infection. It was also observed that drinking tap water, but not contact with animals, was associated with an increased risk for children to be infected (30).

In Egypt, the contact of people with buffaloes and their feces was identified as a risk factor for the prevalence of infection by $G$. duodenalis, drawing attention to zoonotic transmission (32).

In rural regions of India, G. duodenalis and Cryptosporidium spp. have been detected in humans, buffaloes, cattle, goats, sheep, dogs, and water sources (tube wells and lakes). These findings show preliminary evidence of the diversity of possible transmission routes and help to elucidate the distribution of these parasites in coexistence with humans and animals and their water sources (31).

\section{CONTROL AND PREVENTION}

To date, there is still no vaccine or drug that is effective in the treatment of ruminants with cryptosporidiosis, which makes the control of infection difficult. Therefore, the best strategy is to adopt management measures to reduce the spread of the disease in herds $(126,127)$.

The recommended methods for controlling Cryptosporidium spp. infection in ruminants are similar to those recommended for other protozoa and coccidia. Consequently, good breeding practices should be employed out, such as separating animals with diarrhea, cleaning the premises before the animals are introduced, removing and eliminating fecal content or wet garbage, cleaning feeders and drinking fountains, developing strategies to reduce humidity in facilities, and providing adequate supplies of colostrum to neonates $(128,129)$.

The survival time of oocysts can be reduced by freezing, desiccation, exposure to ultraviolet light, and variations in hydrogen potential $(\mathrm{pH})$ and temperature (74). Cryptosporidium spp. oocysts are sensitive to ozone, at temperatures of $55^{\circ} \mathrm{C}$ for $30 \mathrm{~s}$ or $70^{\circ} \mathrm{C}$ for $5 \mathrm{~s}$ (130). Thus, viable solutions for disinfecting the environment consist of $10 \%$ formaldehyde for $18 \mathrm{~h}$ and 5 or $50 \%$ ammonia for $30 \mathrm{~min}(131-133)$.

In some studies, there has been a reduction in the excretion of Cryptosporidium spp. oocysts in cattle calves treated with azithromycin $(134,135)$. Other studies with intestinal microbiota found that fiber deprivation in the diet increases the susceptibility of mice to cryptosporidiosis, and there is a need for research to confirm this possibility in other animal models (136).

Such compounds such as paromomycin (9), albendazole (137, $138)$, and fenbendazole $(9,139)$ can be used for the treatment of giardiasis in cattle calves. The action of probiotics against $G$. duodenalis was primarily investigated in vitro. Probiotics that modulate the immune response have a beneficial effect on the composition of the intestinal microbiota and minimize parasitehost interactions $(140,141)$.

There is no vaccine available for the prevention and control of giardiasis in ruminants (142). Prophylactic measures are similar for the two protozoa and should include complete cleaning and disinfection of housing facilities using such products as ammonia, chlorine dioxide, hydrogen dioxide, and ozone. Additionally, maintaining a dry environment inside buildings may hinder the development of parasites $(46,143)$.

Minimizing the spread of $G$. duodenalis infections among ruminants is a considerable challenge (137). Thus, environmental disinfection associated with drug therapy is recommended $(9,137,138)$. The daily removal of feces in the stable, pens, and surroundings is also important. Additionally, it is essential to ensure adequate intake of colostrum by newborns for the establishment of passive immunity (37). These measures need to be incorporated into the management of the herd with the main priority of adopting good health practices.

\section{CONCLUSION}

Based on recently published research, we demonstrate the global occurrence of Cryptosporidium and $G$. duodenalis in buffaloes from different geographic regions. Although these parasites possess biological differences, they are frequently discussed together because they share transmission pathways and cause diseases in the gastrointestinal tract. Water buffaloes can also become infected and excrete Cryptosporidium spp. oocysts and $G$. duodenalis cysts. In general, young buffaloes are more affected by these agents than are older animals. Infected hosts presenting with and without clinical manifestations can eliminate the infective forms of these protozoa in the environment. Cryptosporidiosis and giardiasis can be diagnosed by a wide variety of parasitological, serological, and molecular techniques. The application of molecular approaches for the identification of these two parasites has led to significant advances in knowledge regarding the epidemiology of these protozoans, with different species being characterized. The common occurrence of these parasites in both buffaloes and humans highlights the potential role of zoonotic transmission in the epidemiology of cryptosporidiosis and giardiasis. However, molecular methods are mostly restricted to research and specialized laboratories, and further research is warranted to determine the taxonomic status and host specificity of these genotypes found in water buffaloes. We recommend that measures need to be incorporated 
into the management of the herd with the main priority of adopting good health practices and highlighting the importance of using molecular tools to identify species/genotypes for a better understanding of the epidemiology of these protozoa relevant in public health.

\section{AUTHOR CONTRIBUTIONS}

All authors have made substantial contributions to the conception of this work and critically reviewed for important intellectual content. We have also collectively approved the

\section{REFERENCES}

1. Xiao L, Fayer R, Ryan U, Upton SJ. Cryptosporidium taxonomy: recent advances and implications for public health. Clin Microbiol Rev. (2004) 17:72-97. doi: 10.1128/CMR.17.1.72-97.2004

2. Santín M. Clinical and subclinical infections with Cryptosporidium in animals. N Z Vet J. (2013) 61:1-10. doi: 10.1080/00480169.2012.731681

3. Feng Y, Ryan UM, Xiao L. Genetic diversity and population structure of Cryptosporidium. Trends Parasitol. (2018) 34:9971011. doi: 10.1016/j.pt.2018.07.009

4. O'Handley RM, Olson ME. Giardiasis and Cryptosporidiosis in ruminants. Vet Clin North Am Food Anim Pract. (2006) 22:623-43. doi: 10.1016/j.cvfa.2006.07.002

5. Cacciò SM, Thompson RCA, McLauchlin J, Smith H V. Unravelling Cryptosporidium and Giardia epidemiology. Trends Parasitol. (2005) 21:4307. doi: 10.1016/j.pt.2005.06.013

6. Efstratiou A, Ongerth JE, Karanis P. Waterborne transmission of protozoan parasites: Review of worldwide outbreaks - an update 2011-2016. Water Res. (2017) 114:14-22. doi: 10.1016/j.watres.2017.01.036

7. Graczyk TK, Grimes BH, Knight R, Silva AJDA, Pieniazek NJ, Veal DA. Detection of Cryptosporidium parvum and Giardia lamblia carried by synanthropic flies by combined fluorescent in situ hybridization and a monoclonal antibody. Am J Trop Med Hyg. (2003) 68:22832. doi: 10.4269 /ajtmh.2003.68.228

8. Hatam-Nahavandil K, Ahmadpour E, Carmena D, Spotin A, Bangoura B, Xiao L. Cryptosporidium infections in terrestrial ungulates with focus on livestock: a systematic review and meta-analysis. Parasites Vectors. (2019) 12:453. doi: 10.1186/s13071-019-3704-4

9. Geurden T, Claerebout E, Dursin L, Deflandre A, Bernay F, Kaltsatos V, et al. The efficacy of an oral treatment with paromomycin against an experimental infection with Giardia in calves. Vet Parasitol. (2006) 135:2417. doi: 10.1016/j.vetpar.2005.09.006

10. Cacciò SM, Rinaldi L, Cringoli G, Condoleo R, Pozio E. Molecular identification of Cryptosporidium parvum and Giardia duodenalis in the Italian water buffalo (Bubalus bubalis). Vet Parasitol. (2007) 150:1469. doi: 10.1016/j.vetpar.2007.09.013

11. Rinaldi L, Musella V, Condoleo R, Saralli G, Veneziano V, Bruni G, et al. Giardia and Cryptosporidium in water buffaloes (Bubalus bubalis). Parasitol Res. (2007) 100:1113-8. doi: 10.1007/s00436-006-0397-3

12. Bhat SA, Juyal PD, Singla LD. Prevalence of cryptosporidiosis in neonatal buffalo calves in Ludhiana district of Punjab, India. Asian J Anim Vet Adv. (2012) 7:512-20. doi: 10.3923/ajava.2012.512.520

13. Feng Y, Raj Karna S, Dearen TK, Singh DK, Adhikari LN, Shrestha A, et al. Common occurrence of a unique Cryptosporidium ryanae variant in zebu cattle and water buffaloes in the buffer zone of the Chitwan National Park, Nepal. Vet Parasitol. (2012) 185:309-14. doi: 10.1016/j.vetpar.2011.09.025

14. Amer S, Zidan S, Feng Y, Adamu H, Li N, Xiao L. Identity and public health potential of Cryptosporidium spp. in water buffalo calves in Egypt. Vet Parasitol. (2013) 191:123-7. doi: 10.1016/j.vetpar.2012.08.015

15. Venu R, Latha BR, Basith SA, Sreekumar C, Raj GD, Raman M. Factors influencing on prevalence of Cryptosporidium infection in south Indian dairy calves. J Parasit Dis. (2013) 37:168-72. doi: 10.1007/s12639-012-0153-9 final version to be published and unanimously agreed with all aspects of this work, ensuring that issues related to the accuracy and integrity of any part of this work are properly investigated and resolved.

\section{FUNDING}

This review was financed by the São Paulo State Research Support Foundation (acronym in Portuguese, FAPESP), process number 2011/525423 and CAPES PROEX 0549/2019. JG is recipient of $\mathrm{CNPq}$ fellowship.

16. Helmy YA, Krücken J, Nöckler K, von Samson-Himmelstjerna G, Zessin KH. Molecular epidemiology of Cryptosporidium in livestock animals and humans in the Ismailia province of Egypt. Vet Parasitol. (2013) 193:1524. doi: 10.1016/j.vetpar.2012.12.015

17. Maurya PS, Rakesh RL, Pradeep B, Kumar S, Kundu K, Garg R, et al. Prevalence and risk factors associated with Cryptosporidium spp. infection in young domestic livestock in India. Trop Anim Health Prod. (2013) 45:9416. doi: 10.1007/s11250-012-0311-1

18. Abeywardena H, Jex AR, von Samson-Himmelstjerna G, Haydon SR, Stevens MA, Gasser RB. First molecular characterisation of Cryptosporidium and Giardia from Bubalus bubalis (water buffalo) in Victoria, Australia. Infect Genet Evol. (2013) 20:96-102. doi: 10.1016/j.meegid.2013.07.019

19. Abeywardena H, Jex AR, Koehler A V., Rajapakse RPVJ, Udayawarna K, Haydon SR, et al. First molecular characterization of Cryptosporidium and Giardia from bovines (Bos taurus and Bubalus bubalis) in Sri Lanka: unexpected absence of C. parvum from pre-weaned calves. Parasit Vectors. (2014) 7:75. doi: 10.1186/1756-3305-7-75

20. Inpankaew T, Jiyipong T, Wongpanit $\mathrm{K}$, Pinyopanuwat $\mathrm{N}$, Chimnoi W, Kengradomkij C, et al. Molecular detection of Cryptosporidium spp. infections in water buffaloes from northeast Thailand. Trop Anim Health Prod. (2014) 46:487-90. doi: 10.1007/s11250-013-0499-8

21. Mahfouz ME lsaye., Mira N, Amer S. Prevalence and genotyping of Cryptosporidium spp. in farm animals in Egypt. J Vet Med Sci. (2014) 76:1569-75. doi: 10.1292/jvms.14-0272

22. Ma J, Li P, Zhao X, Xu H, Wu W, Wang Y, et al. Occurrence and molecular characterization of Cryptosporidium spp. and Enterocytozoon bieneusi in dairy cattle, beef cattle and water buffaloes in China. Vet Parasitol. (2015) 207:220-7. doi: 10.1016/j.vetpar.2014.10.011

23. Aquino MCC, Widmer G, Zucatto AS, Viol MA, Inácio S V., Nakamura AA, et al., Bresciani KDS. First molecular characterization of Cryptosporidium spp. infecting buffalo calves in Brazil. J Eukaryot Microbiol. (2015) 62:65761. doi: $10.1111 /$ jeu. 12223

24. Hingole AC, Gudewar JG, Pednekar RP, Gatne ML. Prevalence and molecular characterization of Cryptosporidium species in cattle and buffalo calves in Mumbai region of India. J Parasit Dis. (2017) 41:1316. doi: 10.1007/s12639-016-0763-8

25. Ibrahim MA, Abdel-Ghany AE, Abdel-Latef GK, Abdel-Aziz SA, Aboelhadid SM. Epidemiology and public health significance of Cryptosporidium isolated from cattle, buffaloes, and humans in Egypt. Parasitol Res. (2016) 115:243948. doi: 10.1007/s00436-016-4996-3

26. Zahedi A, Phasey J, Boland T, Ryan U. First report of Cryptosporidium species in farmed and wild buffalo from the Northern territory, Australia. Parasitol Res. (2016) 115:1349-53. doi: 10.1007/s00436-016-4901-0

27. Utaaker KS, Chaudhary S, Bajwa RS, Robertson LJ. Prevalence and zoonotic potential of intestinal protozoans in bovines in Northern India. Vet Parasitol Reg Stud Rep. (2018) 13:92-7. doi: 10.1016/j.vprsr.2018.03.008

28. Martins TA, Seixas M, Brito DRB, Martins FDC, Cardim ST, Melo P, et al. First identification of Cryptosporidium parvum subtype IIaA20G1R1 in water buffalos (Bubalus bubalis). Res Vet Sci. (2018) 118:181-3. doi: 10.1016/j.rvsc.2018.02.002

29. Russell S, Power M, Ens E. Cryptosporidium and Giardia in feral water buffalo (Bubalus bubalis) in the South East arnhem 
land indigenous protected area, Australia. Parasitol Res. (2020) 119:2149-57. doi: 10.1007/s00436-020-06703-6

30. Helmy YA, Klotz C, Wilking H, Krücken J, Nöckler K, Von SamsonHimmelstjerna G, et al. Epidemiology of Giardia duodenalis infection in ruminant livestock and children in the Ismailia province of Egypt: insights by genetic characterization. Parasit Vectors. (2014) 7:321. doi: 10.1186/1756-3305-7-321

31. Daniels ME, Shrivastava A, Smith WA, Sahu P, Odagiri M, Misra PR, et al. Cryptosporidium and Giardia in humans, domestic animals, and village water sources in rural India. Am J Trop Med Hyg. (2015) 93:596600. doi: 10.4269/ajtmh.15-0111

32. Gharieb RMA, El-Ghany AMA. Giardia lamblia in household persons and buffalo calves; prevalence, molecular identification and associated risk factors. Jpn J Vet Res. (2016) 64:S15-22. Available online at: http://hdl.handle. net/2115/62031

33. Aquino MCC, Harvey TV, Inácio SV, Nagata WB, Ferrari ED, Oliveira BCM, et al. First description of Giardia duodenalis in buffalo calves (Bubalus bubalis) in southwest region of São Paulo State, Brazil. Food Waterborne Parasitol. (2019) 16:e00062. doi: 10.1016/j.fawpar.2019.e00062

34. Bahrami S, Alborzi AR, Molayan PH, Purbaram S, Mousavi B. Prevalence of Cryptosporidium spp. Infection and its association with diarrhea in buffalo calves in Khuzestan, a Southwestern province of Iran. Buffalo Bull. (2014) 33:293-9. Available online at: https://kukr.lib.ku.ac.th/journal/ BuffaloBulletin/search_detail/result/288706

35. Xiao L, Fayer R. Molecular characterisation of species and genotypes of Cryptosporidium and Giardia and assessment of zoonotic transmission. Int J Parasitol. (2008) 38:1239-55. doi: 10.1016/j.ijpara.2008.03.006

36. Shivley CB, Lombard JE, Urie NJ, Kopral CA, Santin M, Earleywine TJ, et al. Preweaned heifer management on US dairy operations : Part VI. Factors associated with average daily gain in preweaned dairy heifer calves. J Dairy Sci. (2018) 101:9245-9258. doi: 10.3168/jds. 2017-14022

37. Santin M. Cryptosporidium and Giardia in Ruminants. Vet Clin North Am Food Anim Pract. (2020) 36:223-38. doi: 10.1016/j.cvfa.2019.11.005

38. Cacciò SM, Lalle M, Svärd SG. Host specificity in the Giardia duodenalis species complex. Infect Genet Evol. (2018) 66:33545. doi: 10.1016/j.meegid.2017.12.001

39. Ryan U, Paparini A, Tong K, Yang R, Gibson-Kueh S, O'Hara A, et al. Cryptosporidium huwi n. sp. (Apicomplexa: Eimeriidae) from the guppy (Poecilia reticulata). Exp Parasitol. (2015) 150:31-5. doi: 10.1016/j.exppara.2015.01.009

40. Kváč M, Havrdová N, Hlásková L, Danková T, Kanděra J, JeŽková J, et al. Cryptosporidium proliferans n. sp. (Apicomplexa: Cryptosporidiidae): molecular and biological evidence of cryptic species within gastric Cryptosporidium of mammals. PLoS ONE. (2016) 11:e0147090. doi: 10.1371/journal.pone.0147090

41. Adl SM, Bass D, Lane CE, Lukeš J, Schoch CL, Smirnov A, et al. Revisions to the classification, nomenclature, and diversity of Eukaryotes. J Eukaryot Microbiol. (2019) 66:4-119. doi: 10.1111/jeu.12691

42. Fayer R. Taxonomy and species delimitation in Cryptosporidium. Exp Parasitol. (2010) 124:90-7. doi: 10.1016/j.exppara.2009.03.005

43. Ren X, Zhao J, Zhang L, Ning C, Jian F, Wang R, et al. Cryptosporidium tyzzeri n. sp. (Apicomplexa: Cryptosporidiidae) in domestic mice (Mus musculus). Exp Parasitol. (2012) 130:274-81. doi: 10.1016/j.exppara.2011.07.012

44. Šlapeta J. Cryptosporidiosis and Cryptosporidium species in animals and humans : a 30 colour rainbow? Int J Parasitol. (2013) 43:95770. doi: 10.1016/j.ijpara.2013.07.005

45. Cunha FS, Peralta JM, Peralta RHS. New insights into the detection and molecular characterization of Cryptosporidium with emphasis in Brazilian studies: a review. Rev Inst Med Trop Sao Paulo. (2019) 61:112. doi: 10.1590/s1678-9946201961028

46. Geurden T, Vercruysse J, Claerebout E. Is Giardia a significant pathogen in production animals? Exp Parasitol. (2010) 124:98106. doi: 10.1016/j.exppara.2009.03.001

47. Yaoyu F, Xiao L. Zoonotic potential and molecular epidemiology of Giardia species and Giardiasis. Clin Microbiol Rev. (2011) 24:11040. doi: 10.1128/CMR.00033-10
48. Checkley W, Jr ACW, Jaganath D, Arrowood MJ, Rachel M, Chen X, et al. A review of the global burden, novel diagnostics, therapeutics, and vaccine targets for Cryptosporidium. Lancet Infect Dis. (2015) 15:8594. doi: 10.1016/S1473-3099(14)70772-8

49. Koehler A V., Jex AR, Haydon SR, Stevens MA, Gasser RB. Giardia/Giardiasis - a perspective on diagnostic and analytical tools. Biotechnol Adv. (2014) 32:280-9. doi: 10.1016/j.biotechadv.2013.10.009

50. Faust EC, Sawitz W, Tobie J, Odom V, Peres C, Lincicome DR. Comparative efficiency of various technics for the diagnosis of protozoa and helminths in feces. J Parasitol. (1939) 25:241-62. doi: 10.2307/3272508

51. Sheather AL. The detection of intestinal protozoa and mange parasites by a floatation technique. J Comp Pathol Ther. (1923) 36:266-75. doi: 10.1016/S0368-1742(23)80052-2

52. Ritchie LS. An ether sedimentation technique for routine stool examinations. Bull US Army Med Dep United States Army Med Dep. (1948) 8:326.

53. Inácio SV, Gomes JF, Oliveira BCM, Falcão AX, Suzuki CTN, dos Santos BM, et al. Validation of a new technique to detect Cryptosporidium spp. oocysts in bovine feces. Prev Vet Med. (2016) 134:1-5. doi: 10.1016/j.prevetmed.2016.09.020

54. Henriksen SA, Pohlenz JF. Staining of cryptosporidia by a modified ZiehlNeelsen technique. Acta Vet Scand. (1981) 22:594-96.

55. Miambo RD, Laitela B, Malatji MP, Afonso SM d. S, Junior AP, Lindh J, et al. Prevalence of Giardia and Cryptosporidium in young livestock and dogs in magude district of Maputo province, Mozambique. Onderstepoort J Vet Res. (2019) 86:e1-6. doi: 10.4102/ojvr.v86i1.1709

56. Ma P, Soave R. Three-step stool examination for cryptosporidiosis in 10 homosexual men with protracted watery diarrhea. J Infect Dis. (1983) 147:824-8. doi: 10.1093/infdis/147.5.824

57. Doungmala P, Phuektes P, Taweenan W, Sangmaneedet S, Japa O. Prevalence and species identification of Cryptosporidium spp. In the newborn dairy calves from Muang District, Khon Kaen Province, Thailand. Vet World. (2019) 12:1454-9. doi: 10.14202/vetworld.2019.1454-1459

58. Baxby D, Blundell N, Hart CA. The development and performance of a simple, sensitive method for the detection of Cryptosporidium oocysts in faeces. J Hyg. (1984) 93:317-23. doi: 10.1017/S0022172400064858

59. Rekha HKM, Puttalakshmamma GC, D'Souza PE. Comparison of different diagnostic techniques for the detection of cryptosporidiosis in bovines. Vet World. (2016) 9:211-215. doi: 10.14202/vetworld.2016.211-215

60. Elliot A, Morgan UM, Thompson RCA. Improved staining method for detecting Cryptosporidium oocysts in stools using malachite green. J Gen Appl Microbiol. (1999) 45:139-42. doi: 10.2323/jgam.45.139

61. Ferrari ED, Nakamura AA, Nardi ARM, Santana BN, da Silva Camargo V, Nagata WB, et al. Cryptosporidium spp. in caged exotic psittacines from Brazil: evaluation of diagnostic methods and molecular characterization. Exp Parasitol. (2018) 184:109-14. doi: 10.1016/j.exppara.2017.12.004

62. Zimmerman SK, Needham CA. Comparison of conventional stool concentration and preserved-smear methods with merifluor Cryptosporidium/Giardia direct immunofluorescence assay and proSpecT Giardia EZ microplate assay for detection of Giardia lamblia. J Clin Microbiol. (1995) 33:1942-3. doi: 10.1128/JCM.33.7.1942-1943.1995

63. Jex AR, Smith H V., Monis PT, Campbell BE, Gasser RB. Cryptosporidium - biotechnological advances in the detection, diagnosis and analysis of genetic variation. Biotechnol Adv. (2008) 26:304-17. doi: 10.1016/j.biotechadv.2008.02.003

64. McHardy IH, Wu M, Shimizu-Cohen R, Roger Couturier M, Humphries RM. Detection of intestinal protozoa in the clinical laboratory. J Clin Microbiol. (2014) 52:712-20. doi: 10.1128/JCM.02877-13

65. Shams S, Abdul Z, Khan W, Campus UCSS. Differential techniques used for detection of Cryptospodidium oocysts in stoll specimens. J Parasit Dis. (2016) 1:1-11.

66. Gallas-Lindemann C, Sotiriadou I, Plutzer J, Noack MJ, Mahmoudi MR, Karanis P. Corrigendum to "Giardia and Cryptosporidium spp. dissemination during wastewatertreatment and comparative detection via immunofluorescence assay (IFA), nested polymerase chain reaction (nested PCR) and loopmediated isothermal amplification (LAMP)". Acta T Acta Trop. (2017) 166:363. doi: 10.1016/j.actatropica.2016.10.026

67. Garcia LS, Shimizu RY, Novak S, Carroll M, Chan F. Commercial assay for detection of Giardia lamblia and Cryptosporidium 
parvum antigens in human fecal specimens by rapid solid-phase qualitative immunochromatography. J Clin Microbiol. (2003) 41:209-12. doi: 10.1128/JCM.41.1.209-212.2003

68. Silva CV, Ferreira MS, Gonçalves-Pires MDRDF, Costa-Cruz JM. Detection of Cryptosporidium - Specific coproantigen in human immunodeficiency virus/acquired immunodeficiency syndrome patients by using a commercially available immunoenzymatic assay. Mem Inst Oswaldo Cruz. (2003) 98:1097-9. doi: 10.1590/S0074-02762003000800022

69. Gündüz N, Arslan MÖ. Determining the prevalence of Cryptosporidium infections with acid fast staining and ELISA in calves at the kars province of Turkey. Turkiye parazitolojii Derg. (2017) 41:5-8. doi: 10.5152/tpd.2017.4833

70. Nash TE.; Herrington DA.; Levine MM. Usefulness of an enzyme-linked immunosorbent assay for detection of Giardia antigen in feces. J Clin Microbiol. (1987) 25:1169-71. doi: 10.1128/JCM.25.7.1169-1171.1987

71. Sulaiman IM, Hira PR, Zhou L, Al-Ali FM, Al-Shelahi FA, Shweiki HM, et al. Unique endemicity of cryptosporidiosis in children in Kuwait. J Clin Microbiol. (2005) 43:2805-9. doi: 10.1128/JCM.43.6.2805-2809.2005

72. Ryan U, Zahedi A, Paparini A. Cryptosporidium in humans and animalsa one health approach to prophylaxis. Parasite Immunol. (2016) 38:53547. doi: 10.1111/pim.12350

73. Ahmed SA, Karanis PSC. Int J Hyg Environ Health. (2018).

74. Xiao L, Morgan UM, Limor J, Escalante A, Arrowood M, Shulaw W, et al. Genetic diversity within Cryptosporidium parvum and related Cryptosporidium species. Appl Environ Microbiol. (1999) 65:3386-91. doi: 10.1128/AEM.65.8.3386-3391.1999

75. Feng Y, Ortega Y, He G, Das P, Xu M, Zhang X, et al. Wide geographic distribution of Cryptosporidium bovis and the deer-like genotype in bovines. Vet Parasitol. (2007) 144:1-9. doi: 10.1016/j.vetpar.2006.10.001

76. Sulaiman IM, Lal AA, Xiao L. Molecular phylogeny and evolutionary relationships of Cryptosporidium parasites at the actin locus. J Parasitol. (2002) 88:388. doi: $10.2307 / 3285594$

77. Khan A, Shaik JS, Grigg ME. Genomics and molecular epidemiology of Cryptosporidium species. Acta Trop. (2018) 184:1-14. doi: 10.1016/j.actatropica.2017.10.023

78. Ryan U, Cacciò SM. Zoonotic potential of Giardia. Int J Parasitol. (2013) 43:943-56. doi: 10.1016/j.ijpara.2013.06.001

79. Wielinga CM, Thompson RCA. Comparative evaluation of Giardia duodenalis sequence data. Parasitology. (2007) 134:1795821. doi: 10.1017/S0031182007003071

80. Ankarklev J, Jerlström-Hultqvist J, Ringqvist E, Troell K, Svärd SG. Behind the smile: cell biology and disease mechanisms of Giardia species. Nat Rev Microbiol. (2010) 8:413-22. doi: 10.1038/nrmicro2317

81. El-Khodery SA, Osman SA. Cryptosporidiosis in buffalo calves (Bubalus bubalis): prevalence and potential risk factors. Trop Anim Health Prod. (2008) 40:419-26. doi: 10.1007/s11250-007-9113-2

82. Fayer R, Trout JM, Jenkins MC. Infectivity of Cryptosporidium parvum oocysts stored in water at environmental temperatures. J Parasitol. (1998) 84:1165. doi: $10.2307 / 3284666$

83. Thompson RCA, Monis PT. Variation in Giardia: Implications for taxonomy and epidemiology. Adv Parasitol. (2004) 58:6937. doi: 10.1016/S0065-308X(04)58002-8

84. Ribeiro MG, Langoni H, Jerez JA, Leite D da S, Ferreira F, Gennari SM. Identification of enteropathogens from buffalo calves with and without diarrhoea in the Ribeira Valley, State of São Paulo, Brazil. Brazilian J Vet Res Anim Sci. (2000) 37:13. doi: 10.1590/S1413-95962000000200013

85. Goraya K, Saeed K, Hashmi HA, Khan MS, Hussain MH. Prevalence and shedding intensity of Giardiasis in naturally infected buffaloes. Int J Agric Biol. (2004) 6:471-3.

86. Xiao L, Feng Y. Food and waterborne parasitology molecular epidemiologic tools for waterborne pathogens Cryptosporidium spp. and Giardia duodenalis. Food Waterborne Parasitol. (2017) 8-9:14-32. doi: 10.1016/j.fawpar.2017.09.002

87. Santín M, Trout JM, Fayer R. A longitudinal study of Giardia duodenalis genotypes in dairy cows from birth to 2 years of age. Vet Parasitol. (2009) 162:40-5. doi: 10.1016/j.vetpar.2009.02.008

88. Khan SM, Debnath C, Pramanik AK, Xiao L, Nozaki T, Ganguly S. Molecular characterization and assessment of zoonotic transmission of Cryptosporidium from dairy cattle in West Bengal, India. Vet Parasitol. (2010) 171:41-7. doi: 10.1016/j.vetpar.2010.03.008
89. Langkjær RB, Vigre H, Enemark HL, Maddox-Hyttel C. Molecular and phylogenetic characterization of Cryptosporidium and Giardia from pigs and cattle in Denmark. Parasitology. (2007) 134:339-50. doi: 10.1017/S0031182006001533

90. Robinson G, Chalmers RM, Stapleton C, Palmer SR, Watkins J, Francis C, et al. A whole water catchment approach to investigating the origin and distribution of Cryptosporidium species. J Appl Microbiol. (2011) 111:71730. doi: 10.1111/j.1365-2672.2011.05068.x

91. Wang H, Zhao G, Chen G, Jian F, Zhang S, Feng C, et al. Multilocus genotyping of Giardia duodenalis in dairy cattle in Henan, China. PLoS ONE. (2014) 9:e0100453. doi: 10.1371/journal.pone.0100453

92. Qi M, Wang H, Jing B, Wang R, Jian F, Ning C, et al. Prevalence and multilocus genotyping of Giardia duodenalis in dairy calves in Xinjiang, Northwestern China. Parasit Vectors. (2016) 1-6. doi: 10.1186/s13071-016-1828-3

93. Savioli L, Smith H, Thompson A. Giardia and Cryptosporidium join the "Neglected diseases initiative." Trends Parasitol. (2006) 22:2038. doi: 10.1016/j.pt.2006.02.015

94. Karanis P, Kourenti C, Smith H. Waterborne transmission of protozoan parasites: a worldwide review of outbreaks and lessons learnt. J Water Health. (2007) 5:1-38. doi: 10.2166/wh.2006.002

95. Mackenzie WR, Hoxie NJ, Proctor ME, Gradus MS, Blair KA, Peterson DE, et al. A massive outbreak in Milwaukke of Cryptosporidium infection transmitted through the public water supply. N Engl J Med. (1994) 331:161167. doi: 10.1056/NEJM199407213310304

96. Corso PS, Kramer MH, Blair KA, Addiss DG, Davis JP, Haddix AC. Cost of illness in the 1993 waterborne Cryptosporidium outbreak, Milwaukee, Wisconsin. Emerg Infect Dis. (2003) 9:426-31. doi: 10.3201/eid0904.020417

97. Ortega-pierres MG, Jex AR, Ansell BRE, Svärd SG. Recent advances in the genomic and molecular biology of Giardia. Acta Trop. (2017) 184:6772. doi: 10.1016/j.actatropica.2017.09.004

98. Abeywardena H, Jex AR, Gasser RB. A perspective on Cryptosporidium and Giardia, with an emphasis on bovines and recent epidemiological findings. Adv Parasitol. (2015) 88:243-301. doi: 10.1016/bs.apar.2015.02.001

99. Smith H V., Cacciò SM, Tait A, McLauchlin J, Thompson RCA. Tools for investigating the environmental transmission of Cryptosporidium and Giardia infections in humans. Trends Parasitol. (2006) 22:1607. doi: 10.1016/j.pt.2006.02.009

100. Ong CSL, Eisler DL, Alikhani A, Fung VWK, Tomblin J, Bowie WR, et al. Novel Cryptosporidium genotypes in sporadic cryptosporidiosis cases: first report of human infections with a cervine genotype. Emerg Infect Dis. (2002) 8:263-8. doi: 10.3201/eid0803.010194

101. Pieniazek NJ, Bornay-Llinares FJ, Slemenda SB, Da Silva AJ, Moura INS, Arrowood MJ, et al. New Cryptosporidium genotypes in HIV-infected persons. Emerg Infect Dis. (1999) 5:444-9. doi: 10.3201/eid0503.990318

102. Pedraza-Díaz S, Amar C, McLauchlin J. The identification and characterisation of an unusual genotype of Cryptosporidium from human faeces as Cryptosporidium meleagridis. FEMS Microbiol Lett. (2000) 189:189-94. doi: 10.1016/S0378-1097(00)00278-0

103. Cama VA, Bern C, Sulaiman IM, Gilman RH, Ticona E, Vivar A, et al. Cryptosporidium species and genotypes in HIVpositive patients in lima, Peru. J Eukaryot Microbiol. (2003) 50:531-3. doi: 10.1111/j.1550-7408.2003.tb00620.x

104. Palmer CJ, Xiao L, Terashima A, Guerra H, Gotuzzo E, Saldías G, et al. Cryptosporidium muris, a rodent pathogen, recovered from a human in Perú. Emerg Infect Dis. (2003) 9:1174-6. doi: 10.3201/eid0909.030047

105. Gatei W, Wamae CN, Mbae C, Waruru A, Mulinge E, Waithera T, et al. Cryptosporidiosis: prevalence, genotype analysis, and symptoms associated with infections in children in Kenya. Am J Trop Med Hyg. (2006) 75:7882. doi: 10.4269/ajtmh.2006.75.78

106. Leoni F, Amar C, Nichols G, Pedraza-Díaz S, McLauchlin J. Genetic analysis of Cryptosporidium from 2414 humans with diarrhoea in England between 1985 and 2000. J Med Microbiol. (2006) 55:7037. doi: 10.1099/jmm.0.46251-0

107. Chalmers RM, Robinson G, Elwin K, Hadfield SJ, Xiao L, Ryan U, et al. Cryptosporidium sp. rabbit genotype, a newly identified human pathogen. Emerg Infect Dis. (2009) 15:829-30. doi: 10.3201/eid1505.081419

108. Puleston RL, Mallaghan CM, Modha DE, Hunter PR, Nguyen-Van-Tam JS, Regan CM, et al. The first recorded outbreak of cryptosporidiosis due 
to Cryptosporidium cuniculus (formerly rabbit genotype), following a water quality incident. J Water Health. (2014) 12:41-50. doi: 10.2166/wh.2013.097

109. McLauchlin J, Amar C, Pedraza-Díaz S, Nichols GL. Molecular epidemiological analysis of Cryptosporidium spp. in the United Kingdom: results of genotyping Cryptosporidium spp. in 1,705 Fecal samples from humans and 105 fecal samples from livestock animals. J Clin Microbiol. (2000) 38:3984-90. doi: 10.1128/JCM.38.11.3984-3990.2000

110. Morgan U, Weber R, Xiao L, Sulaiman I, Thompson RCA, Ndiritu W, et al. Molecular characterization of Cryptosporidium isolates obtained from human immunodeficiency virus-infected individuals living in Switzerland, Kenya, and the United States. J Clin Microbiol. (2000) 38:11803. doi: 10.1128/JCM.38.3.1180-1183.2000

111. Kopacz Z, Kvá M, Karpinski P, Hendrich AB, Sasiadek MM, Leszczynski $\mathrm{P}$, et al. The first evidence of Cryptosporidium meleagridisInfection in a colon adenocarcinoma from an immunocompetent patient. Front Cell Infect Microbiol. (2019) 9:35. doi: 10.3389/fcimb.2019.00035

112. Gelanew T, Lalle M, Hailu A, Pozio E, Cacciò SM. Molecular characterization of human isolates of Giardia duodenalis from Ethiopia. Acta Trop. (2007) 102:92-9. doi: 10.1016/j.actatropica.2007.04.003

113. Štrkolcová G, Madár M, Hinney B, Goldová M, MojŽišová J, Halánová M. Dog's genotype of Giardia duodenalis in human: first evidence in Europe. Acta Parasitol. (2015) 60:796-9. doi: 10.1515/ap-2015-0113

114. Foronda P, Bargues MD, Abreu-Acosta N, Periago MV, Valero MA, Valladares B, et al. Identification of genotypes of Giardia intestinalis of human isolates in Egypt. Parasitol Res. (2008) 103:1177-81. doi: 10.1007/s00436-008-1113-2

115. Fantinatti M, Bello AR, Fernandes O, Da-Cruz AM. Identification of Giardia lamblia assemblage e in humans points to a new anthropozoonotic cycle. $J$ Infect Dis. (2016) 214:1256-9. doi: 10.1093/infdis/jiw361

116. Zahedi A, Field D, Ryan U. Molecular typing of Giardia duodenalis in humans in Queensland-first report of assemblage E. Parasitology. (2017) 144:1154-61. doi: 10.1017/S0031182017000439

117. Berrilli F, D’Alfonso R, Giangaspero A, Marangi M, Brandonisio O, Kaboré $\mathrm{Y}$, et al. Giardia duodenalis genotypes and Cryptosporidium species in humans and domestic animals in Côte d'Ivoire: occurrence and evidence for environmental contamination. Trans R Soc Trop Med Hyg. (2012) 106:1915. doi: 10.1016/j.trstmh.2011.12.005

118. Wang G, Wang G, Li X, Zhang X, Karanis G, Jian Y, et al. Prevalence and molecular characterization of Cryptosporidium spp. and Giardia duodenalis in 1-2-month-old highland yaks in Qinghai Province, China. Parasitol Res. (2018) 117:1793-800. doi: 10.1007/s00436-018-5861-3

119. Khalil IA, Troeger C, Rao PC, Blacker BF, Brown A, Brewer TG, et al. Morbidity, mortality, and long-term consequences associated with diarrhoea from Cryptosporidium infection in children younger than 5 years: a meta-analyses study. Lancet Glob Heal. (2018) 6:e75868. doi: 10.1016/S2214-109X(18)30283-3

120. Bartelt LA, Sartor RB. Advances in understanding Giardia: determinants and mechanisms of chronic sequelae. F1000Prime Rep. (2015) 7:62. doi: 10.12703/P7-62

121. Cotton JA, Beatty JK, Buret AG. Host parasite interactions and pathophysiology in Giardia infections. Int $J$ Parasitol. (2011) 41:925-33. doi: 10.1016/j.ijpara.2011.05.002

122. Hanevik K, Dizdar V, Langeland N, Hausken T. Development of functional gastrointestinal disorders after Giardia lamblia infection. BMC Gastroenterol. (2009) 9:27. doi: 10.1186/1471-230X-9-27

123. Robertson LJ, Hanevik K, Escobedo AA, Mørch K, Langeland N. Giardiasiswhy do the symptoms sometimes never stop? Trends Parasitol. (2010) 26:75-82. doi: 10.1016/j.pt.2009.11.010

124. Thompson RCA, Ash A. Molecular epidemiology of Giardia and Cryptosporidium infections. Infect Genet Evol. (2016) 40:315-23. doi: 10.1016/j.meegid.2015.09.028

125. Abdel-Moein KA, Saeed H. The zoonotic potential of Giardia intestinalis assemblage $\mathrm{E}$ in rural settings. Parasitol Res. (2016) 115:3197-202. doi: 10.1007/s00436-016-5081-7

126. de Graaf DC, Vanopdenbosch E, Ortega-mora LM, Abbassi H, Peeters JE. A review of the importance of cryptosporidiosis in farm animals. Int J Parasitol. (1999) 29:1269-87. doi: 10.1016/S0020-7519(99)00076-4

127. Fayer R, Trout J, Graczyk T, Lewis E. Prevalence of Cryptosporidium, Giardia and Eimeria infections in post-weaned and adult cattle on three Maryland farms. Vet Parasitol. (2000) 93:103-12. doi: 10.1016/S0304-4017(00) 00356-3

128. Harp JA, Goff JP. Strategies for the control of Cryptosporidium parvum infection in calves. J Dairy Sci. (1998) 81:28994. doi: 10.3168/jds.S0022-0302(98)75578-X

129. Cosendey RIJ, Fiuza VRS, Oliveira FCRDE. Importância do manejo na criptosporidiose em criações de ovinos. Rev Bras Parasitol Veterinária. (2008) 17:209-14. Available online at: https://www.redalyc.org/pdf/3978/ 397841469045.pdf

130. Fujino T, Matsui T, Kobayashi F, Haruki K, Yoshino Y, Kajima J, et al. The effect of heating against Cryptosporidium oocysts. J Vet Med Sci. (2002) 64:199-200. doi: 10.1292/jvms.64.199

131. Campbell I, Tzipori AS, Hutchison G, Angus KW. Effect of disinfectants on survival of Cryptosporidium oocysts. Vet Rec. (1982) 111:4145. doi: 10.1136/vr.111.18.414

132. Campbell AT, Robertson LJ, Smith H V. Effects of preservatives on viability of Cryptosporidium parvum oocysts. Appl Environ Microbiol. (1993) 59:43612. doi: 10.1128/AEM.59.12.4361-4362.1993

133. Sundermann CA, Lindsay DS, Blagburn BL. Evaluation of disinfectants for ability to kill avian Cryptosporidium oocysts. Companion Anim Pract. (1987) 1:36-9.

134. Marcos LA, Gotuzzo E. Intestinal protozoan infections in the immunocompromised host. Curr Opin Infect Dis. (2013) 26:295-301. doi: 10.1097/QCO.0b013e3283630be3

135. Kotloff KL, Nataro JP, Blackwelder WC, Nasrin D, Farag TH, Panchalingam $S$, et al. Burden and aetiology of diarrhoeal disease in infants and young children in developing countries (the global enteric multicenter study, GEMS): a prospective, case-control study. Lancet. (2013) 382:20922. doi: 10.1016/S0140-6736(13)60844-2

136. Oliveira BCM, Bresciani KDS, Widmer G. Deprivation of dietary fiber enhances susceptibility of mice to cryptosporidiosis. PLoS Negl Trop Dis. (2019) 13:e0007411. doi: 10.1371/journal.pntd.0007411

137. O'Handley RM, Olson ME, Fraser D, Adams P, Thompson RCA. Prevalence and genotypic characterisation of Giardia in dairy calves from Western Australia and Western Canada. Vet Parasitol. (2000) 90:193200. doi: 10.1016/S0304-4017(00)00235-1

138. Xiao L, Saeed K, Herd RP. Efficacy of albendazole and fenbendazole against Giardia infection in cattle. Vet Parasitol. (1996) 61:165-70. doi: 10.1016/0304-4017(95)00802-0

139. Blanco YAC, de Barbieri JM, de Lima RR, Lopes MA, Reis EMB, da Rocha CMBM, et al. Economic evaluation and efficacy of strategic-selective treatment of gastrointestinal parasites in dairy calves. Rev Bras Parasitol Vet. (2017) 26:123--8. doi: 10.1590/s1984-29612017020

140. Ventura LLA, de Oliveira DR, Gomes MA, Torres MRF. Effect of probiotics on Giardiasis. Where are we? Brazilian J Pharm Sci. (2018) 54:217360. doi: 10.1590/s2175-97902018000217360

141. Perrucci S, Fichi G, Ricci E, Galosi L, Lalle M, Rossi G. In vitro and ex vivo evaluation of the anti-Giardia duodenalis activity of the supernatant of Slab51 (SivoMixx). PLoS ONE. (2019) 14:e0213385. doi: 10.1371/journal.pone.0213385

142. Olson ME, Ceri H, Morck DW. Giardia vaccination. Parasitol Today. (2000) 16:213-7. doi: 10.1016/S0169-4758(99)01623-3

143. Saleh MN, Gilley AD, Byrnes MK, Zajac AM. Development and evaluation of a protocol for control of Giardia duodenalis in a colony of grouphoused dogs at a veterinary medical college. J Am Vet Med Assoc. (2016) 249:644-9. doi: 10.2460/javma.249.6.644

Conflict of Interest: The authors declare that the research was conducted in the absence of any commercial or financial relationships that could be construed as a potential conflict of interest.

Copyright (c) 2020 de Aquino, Inácio, Rodrigues, de Barros, Garcia, Headley, Gomes and Bresciani. This is an open-access article distributed under the terms of the Creative Commons Attribution License (CC BY). The use, distribution or reproduction in other forums is permitted, provided the original author(s) and the copyright owner(s) are credited and that the original publication in this journal is cited, in accordance with accepted academic practice. No use, distribution or reproduction is permitted which does not comply with these terms. 